\title{
Selective Calcium-Dependent Inhibition of ATP-Gated P2X3 Receptors by Bisphosphonate-Induced Endogenous ATP Analog ApppI
}

\author{
Yevheniia Ishchenko, Anastasia Shakirzyanova, Raisa Giniatullina, Andrei Skorinkin, \\ Genevieve Bart, Petri Turhanen, Jorma A. Määttä, Jukka Mönkkönen, and Rashid Giniatullin \\ A. I. Virtanen Institute (Y.I., A.Sh., Rai.G., G.B., Ras.G.) and School of Pharmacy (P.T., J. M.), University of Eastern Finland, \\ Kuopio, Finland; Kazan Institute of Biochemistry and Biophysics, Kazan, Russia (A.Sh., A.Sk.); Institute of Biomedicine, \\ University of Turku, Turku, Finland (J.A.M.); and Kazan Federal University, Kazan, Russia (A.Sh., A.Sk., R.Gas.)
}

Received November 16, 2016; accepted April 7, 2017

\begin{abstract}
Pain is the most unbearable symptom accompanying primary bone cancers and bone metastases. Bone resorptive disorders are often associated with hypercalcemia, contributing to the pathologic process. Nitrogen-containing bisphosphonates (NBPs) are efficiently used to treat bone cancers and metastases. Apart from their toxic effect on cancer cells, NBPs also provide analgesia via poorly understood mechanisms. We previously showed that NBPs, by inhibiting the mevalonate pathway, induced formation of novel ATP analogs such as ApppI [1-adenosin-5'-yl ester 3-(3methylbut-3-enyl) triphosphoric acid diester], which can potentially be involved in NBP analgesia. In this study, we used the patchclamp technique to explore the action of ApppI on native ATPgated $P 2 X$ receptors in rat sensory neurons and rat and human P2X3, P2X2, and P2X7 receptors expressed in human embryonic kidney cells. We found that although ApppI has weak agonist
\end{abstract}

activity, it is a potent inhibitor of $\mathrm{P} 2 \mathrm{X} 3$ receptors operating in the nanomolar range. The inhibitory action of ApppI was completely blocked in hypercalcemia-like conditions and was stronger in human than in rat $\mathrm{P} 2 \mathrm{X} 3$ receptors. In contrast, $\mathrm{P} 2 \mathrm{X} 2$ and $\mathrm{P} 2 \mathrm{X} 7$ receptors were insensitive to ApppI, suggesting a high selectivity of ApppI for the P2X3 receptor subtype. NBP, metabolite isopentenyl pyrophosphate, and endogenous AMP did not exert any inhibitory action, indicating that only intact ApppI has inhibitory activity. $\mathrm{Ca}^{2+}$-dependent inhibition was stronger in trigeminal neurons preferentially expressing desensitizing P2X3 subunits than in nodose ganglia neurons, which also express nondesensitizing P2X2 subunits. Altogether, we characterized previously unknown purinergic mechanisms of NBP-induced metabolites and suggest ApppI as the endogenous pain inhibitor contributing to cancer treatment with NBPs.

\section{Introduction}

Patients with primary bone cancers or bone metastases from breast and prostate cancer experience a high level of pain, which remains intractable in many cases (Mantyh, 2014; Maier et al., 2015; van den Beuken-van Everdingen et al., 2016).

Bisphosphonates are among the most specific bone cancer treatments available to date (Lin, 1996; Kavanagh et al., 2006; Russell, 2011; Debiais, 2013; Coleman et al., 2014). Bisphosphonates are divided into two main groups: 1) simple bisphosphonates without a nitrogen group and 2) the most promising third-generation nitrogen-containing bisphosphonates (NBPs) (Frith et al., 2001; Rogers et al., 2011). NBPs also have an antinociceptive effect (Kavanagh et al., 2006; Fujita et al., 2009), which contributes to their therapeutic effect (Abe et al.,

This research was supported by the Finnish Academy [Grant 277442] https://doi.org/10.1124/jpet.116.238840.
2011; Maier et al., 2015). However, the mechanisms of NBP analgesia remain unclear. We previously showed that inhibition of farnesyl-diphosphate synthase by the NBP zoledronate (Mönkkönen et al., 2006; Räikkönen et al., 2009, 2010, 2011) induces formation of the ATP analog ApppI [1-adenosin-5'-yl ester 3-(3-methylbut-3-enyl) triphosphoric acid diester], which can produce a toxic effect on osteoclasts and tumor cells (Lehenkari et al., 2002; Green, 2004; Mönkkönen et al., 2006). However, the interaction of ApppI with the nociceptive system has not yet been characterized. Since ApppI structurally resembles the antinociceptive diadenosine polyphosphates (Viatchenko-Karpinski et al., 2016), we investigated the effects of the NBP-induced derivative ApppI on the activity of nociceptive receptors $\mathrm{P} 2 \mathrm{X} 2$, P2X3, and P2X7.

P2X3 receptors implicated in neuropathic (McGaraughty et al., 2003; Chen et al., 2005) and inflammatory pain (Cockayne et al., 2000; Souslova et al., 2000) are almost exclusively expressed in nociceptive neurons (Chen et al., 1995; Lewis et al., 1995). Notably, they are expressed in terminals of C- and A $\delta$-fibers

ABBREVIATIONS: A-317491, 5-[(3-phenoxyphenyl)methyl-[(1S)-1,2,3,4-tetrahydronaphthalen-1-yl]carbamoyl]benzene-1,2,4-tricarboxylic acid; ApppI, 1-adenosin-5'-yl ester 3-(3-methylbut-3-enyl) triphosphoric acid diester; GFP, green fluorescent protein; HEK, human embryonic kidney; IPP, isopentenyl pyrophosphate; NBP, nitrogen-containing bisphosphonate; NMR, nuclear magnetic resonance; TMSB, Trizma-maleate sucrose buffer. 
innervating the bone (Hukkanen et al., 1992; Mach et al., 2002; Kaan et al., 2010; Falk et al., 2012; Zhao and Levy, 2014). There is abundant evidence of the involvement of P2X3 receptors in cancer pain (Kaan et al., 2010; Falk et al., 2012; Hansen et al., 2012; Wu et al., 2012; Burnstock and Di Virgilio, 2013). Interestingly, unlike in rodent models, the P2X3 receptor subtype in human nociceptive neurons of the dorsal root ganglion does not express heterotrimeric functional receptors with P2X2 subunits (Serrano et al., 2012), meaning that homomeric P2X3 is the main receptor involved in nociception in bone cancer. The P2X3 and P2X2/3 receptor antagonist A-317491 (5-[(3-phenoxyphenyl)methyl[(1S)-1,2,3,4-tetrahydronaphthalen-1-yl]carbamoyl]benzene1,2,4-tricarboxylic acid) attenuated bone cancer-induced pain in mice transiently but had no effect in the late stage of the malignant process (Hansen et al., 2012). The increased expression of P2X3 receptors in calcitonin gene-related peptide-containing nerve fibers during tumor growth also suggests a role for ATP receptors in cancer-related pain (Gilchrist et al., 2005). Another study also found that $\mathrm{P} 2 \mathrm{X} 3$ receptors are functionally upregulated in the dorsal root ganglia in a rat model of bone cancer (Wu et al., 2012).

Growing evidence suggests that cancer-related bone pain is associated with osteoclast activation (Luger et al., 2005; Nagae et al., 2006) and $\mathrm{Ca}^{2+}$ misbalance. In some pathologic conditions such as parathyroid hormone-related proteinmediated hypercalcemic crisis, serum $\mathrm{Ca}^{2+}$ reaches hypercalcemic levels that increase from a normal level of approximately $2 \mathrm{mM}$ up to $3.5 \mathrm{mM}$ (Rahil and Khan, 2012; Fijorek et al., 2014). In addition, malignancy-associated hypercalcemia is often associated with headache (Stewart, 2005; Basso et al., 2011; Hu et al., 2013; Goldner, 2016; Tagiyev et al., 2016). Notably, serum $\mathrm{Ca}^{2+}$ levels can be elevated in malignancy (to $4 \mathrm{mM}$ or more in the most severe cases) (Goldner, 2016); however, in the clinic, hypercalcemia decreased 24-48 hours after NBP treatment and the serum $\mathrm{Ca}^{2+}$ level was normalized for $60 \%-90 \%$ of patients after 4-7 days of NBP treatment (Stewart, 2005; Endres, 2012).

Extracellular $\mathrm{Ca}^{2+}$ plays an important role in P2X3 signaling (Cook and McCleskey, 1997; Cook et al., 1998). Thus, elevated $\mathrm{Ca}^{2+}$ accelerates resensitization of these receptors (Cook and McCleskey, 1997; Cook et al., 1998; Giniatullin et al., 2003), making them functionally more active. In contrast, $\mathrm{Ca}^{2+}$-free solution prolongs the ATP-evoked inactive desensitized P2X3 receptor state (Cook et al., 1998; Giniatullin et al., 2003).

Here, we show strong $\mathrm{Ca}^{2+}$-dependent inhibition of the pronociceptive P2X3 receptors by low nanomolar concentrations of ApppI. Our data predict that the antinociceptive action of ApppI should be largely enhanced when the concentration of $\mathrm{Ca}^{2+}$ decreases in response to NBP treatment. Thus, we propose that ApppI generated by cancer treatment with NBPs (e.g., zoledronate) can contribute to pain relief via the selective inhibition of ATP-gated P2X3 receptors in the sensory neurons.

\section{Materials and Methods}

All animal use protocols were in accordance with recommendations of the Federation for Laboratory Animal Science Associations and were approved by the local institutional animal care and use committees. Wistar rats (P10-12 and P35-38) were obtained from the Animal Facilities of the University of Eastern Finland (Kuopio, Finland). Experiments were designed to minimize the number of animals used in research.

\section{Cell Culture and Transfection}

Trigeminal and nodose ganglia cells from Wistar male rats (P10-12) were prepared as described previously (Simonetti et al., 2006; Li and Schild, 2007; Yegutkin et al., 2016) with minor modifications. Briefly, after decapitation, trigeminal and nodose ganglia were isolated and dissociated in an enzymatic cocktail containing collagenase, trypsin, and DNAase (Sigma-Aldrich, St. Louis, MO) added to F-12 media (Gibco/Invitrogen, Grand Island, NY) under continuous mixing (900 rpm) in an Eppendorf ThermoMixer (Eppendorf, Hamburg, Germany) at $37^{\circ} \mathrm{C}$ for 15 minutes. After dissociation, cells were resuspended in fresh F-12 media, centrifuged at $1000 \mathrm{rpm}$ for 5 minutes at room temperature, and plated on coverslips coated with poly(L-lysine) (Sigma-Aldrich). Cells were maintained in F-12 GlutaMAX medium containing $10 \%$ fetal bovine serum (Gibco) and $100 \mathrm{U} / \mathrm{ml}$ penicillin and streptomycin at $37^{\circ} \mathrm{C}$ in a $5 \% \mathrm{CO}_{2}$ atmosphere in a humidified incubator. Cells were used for experiments 48 hours after plating.

Human embryonic kidney HEK293 and HEK293T cell cultures were maintained as reported previously (Fabbretti et al., 2004; Viatchenko-Karpinski et al., 2016) in Dulbecco's modified Eagle's medium (Gibco/Invitrogen) supplemented with $10 \%$ fetal bovine serum and antibiotics. Cells were passaged at $80 \%$ confluence. HEK cells were transiently transfected in a 12 -well plate $\left(10^{5}\right.$ cells per well $)$ using FugeneHD (Promega, Madison, WI) (Jindrichova et al., 2011). Twelve hours after transfection, cells were replated on coverslips coated with poly(L-lysine) (Sigma-Aldrich). Transfection was performed with cDNA encoding rat $\mathrm{rP} 2 \mathrm{X} 3$ tagged with green fluorescent protein (GFP) (rP2X3-GFP), rP2X2-GFP, and rP2X7-GFP and human hP2X3, hP2X2, and hP2X7 (GFP added separately). Sufficient receptor expression was observed in 24 hours for recombinant $r P 2 X s$ and 48-72 hours for the hP2Xs homolog when cells were used for electrophysiological experiments.

Electrophysiological Recording and Solutions. Whole-cell patch-clamp recordings from HEK293 cells and trigeminal and nodose ganglia neurons were performed using a HEKA-10 amplifier with HEKA PatchMaster software at a holding potential of $-70 \mathrm{mV}$ (HEKA Elektronik, Holliston, MA). Glass electrodes (3-6 M $\Omega$ ) filled with intracellular solution containing $130 \mathrm{mM} \mathrm{CsCl}, 5 \mathrm{mM} \mathrm{MgCl}, 10 \mathrm{mM}$ HEPES, 5 mM EGTA, $0.5 \mathrm{mM} \mathrm{CaCl}_{2}$, 2 mM Mg-ATP, $0.5 \mathrm{mM}$ Na-GTP, and $5 \mathrm{mM} \mathrm{KCl}, \mathrm{pH} 7.2$, adjusted by $\mathrm{CsOH}$ were used for the current recordings. During the experiment, cells were superfused $(2 \mathrm{ml} / \mathrm{min})$ with basic extracellular solution containing $148 \mathrm{mM} \mathrm{NaCl}, 5 \mathrm{mM} \mathrm{KCl}$, $1 \mathrm{mM} \mathrm{MgCl} 2,2 \mathrm{mM} \mathrm{CaCl}_{2}, 10$ HEPES, and 10 D-glucose, $\mathrm{pH} \mathrm{7.4,}$ adjusted by $\mathrm{NaOH}$.

Drug Delivery. P2X receptors were activated by fast agonist application (exchange time of approximately 30 milliseconds) using the rapid solution exchange system (RSC-200; Bio-Logic Science Instruments, Seyssinet-Pariset, France) synchronized with a HEKA amplifier. Application tubes were placed approximately 100-150 $\mu \mathrm{m}$ from cell recordings. Stocks of $\alpha, \beta$-meATP, ATP, ApppI, isopentenyl pyrophosphate (IPP), and zoledronate were prepared in ultrapure water and diluted to the final concentrations before the experiment. The duration of agonist applications ( $\alpha, \beta$-meATP, ATP, and ApppI) was typically 2 seconds unless indicated otherwise. ApppI, IPP, zoledronate, and AMP inhibitory activity was tested by applying the compounds for 120 seconds between the test pulses.

\section{Synthesis of ApppI and IPP}

The ATP analog ApppI was synthesized as previously reported (Weisell et al., 2015). The purity of ApppI was $\geq 95 \%$, as determined from ${ }^{1} \mathrm{H}$ and ${ }^{31} \mathrm{P}$ nuclear magnetic resonance (NMR) spectra. The purified ApppI tris(triethylammonium) salt was highly stable based on the ${ }^{1} \mathrm{H}$ and ${ }^{31} \mathrm{P}$ NMR spectra in samples stored in $\mathrm{D}_{2} \mathrm{O}$ for approximately 1.5 years at room temperature. IPP was prepared from pyrophosphate tris(tetrabutylammonium) salt and isopentenyl tosylate (Kao et al., 2005; Weisell et al., 2015). The purity of IPP was $\geq 95 \%$ according to ${ }^{1} \mathrm{H}$ and ${ }^{31} \mathrm{P}$ NMR spectra (Weisell et al., 2015). 


\section{Phosphate Enzymatic Histochemistry}

Rat hemiskulls were prepared as previously described (Yegutkin et al., 2016). Briefly, the skull was cut along the sagittal suture into two halves. The brain was gently removed, leaving the dura mater intact and attached to the skull cavity. Hemiskulls were then placed in an aerator with $5 \% \mathrm{CO}_{2} / 95 \% \mathrm{O}_{2}$ artificial cerebrospinal fluid containing $5 \mathrm{mM} \mathrm{KCl}, 119 \mathrm{mM} \mathrm{NaCl}, 18 \mathrm{mM}$ glucose, $2.7 \mathrm{mM} \mathrm{CaCl}_{2}, 0.5 \mathrm{mM}$ $\mathrm{MgCl}, 1.1 \mathrm{mM} \mathrm{NaH}_{2} \mathrm{PO}_{4}$, and $30 \mathrm{mM} \mathrm{NaHCO}_{3}, \mathrm{pH}$ 7.4. A modification of the lead nitrate $\left[\mathrm{Pb}\left(\mathrm{NO}_{3}\right)_{2}\right]$ method was used to evaluate ApppI and ATP degradation (Mercier et al., 2012). In brief, after 30 minutes of washing in aerated artificial cerebrospinal fluid, hemiskulls were washed with Trizma-maleate buffer ( $40 \mathrm{mM}$ Trizma maleate; SigmaAldrich) and then preincubated for 45 minutes in Trizma-maleate sucrose buffer (TMSB) (with $0.25 \mathrm{M}$ sucrose, $\mathrm{pH} 7,4$ ) containing the alkaline phosphatase inhibitor levamisole ( $2 \mathrm{mM}$; Sigma-Aldrich). For the next 40 minutes, hemiskulls were incubated with ATP or ApppI (both $300 \mu \mathrm{M}$ ) in TMSB-buffered solutions with freshly added $2 \mathrm{mM}$ $\mathrm{Pb}\left(\mathrm{NO}_{3}\right)_{2}$ after washing in Trizma-maleate buffer. The same amount of incubation medium was used for blank specimens. Samples treated with $0.5 \%\left(\mathrm{NH}_{4}\right)_{2} \mathrm{~S}$ (Sigma-Aldrich) formed the lead orthophosphate precipitates, which presented as brown deposits. After three washings in TMSB, stained meninges were carefully removed from hemiskulls and mounted on glass slides coated with poly(lysine) (Polysine; Thermo Fisher Scientific, Waltham, MA). Slides were mounted with Aquatex mounting medium (Merck, Kenilworth, NJ). An Olympus BX60 microscope with an Olympus DP71 camera with a PlanC $\times 4 / 0.10$ or UPlanFL $\times 10 / 0.30$ objective (Olympus, Tokyo, Japan) was used to acquire images. All images were taken with standard settings for further analysis with CorelDRAW Graphics Suite software (version 17; Corel, Ottawa, ON, Canada).

To quantify histochemical images, signal intensity was evaluated in each stained sample from the region of the interest located in similar areas around meningeal vessels with the same diameter (approximately 60-95 $\mu \mathrm{m})$.

\section{ATP Luminescence Assay}

ATP release from the trigeminal ganglion cells (obtained from P10-12 rats) was measured with the ATPlite Luminescence Assay System (catalog no. 6016941; PerkinElmer, Waltham, MA). Cells were cultured in a 24 -well plate for 48 hours. Growth medium was then changed with fresh medium (control) or with fresh medium containing $100 \mu \mathrm{M}$ zoledronate. After 24 hours of treatment, cells were washed and the bathing medium was changed with basic salt solution containing $152 \mathrm{mM} \mathrm{NaCl}, 2.5 \mathrm{mM} \mathrm{KCl}, 2 \mathrm{mM} \mathrm{CaCl}_{2}, 1 \mathrm{mM}$ $\mathrm{MgCl}_{2}, 10 \mathrm{mM}$ glucose, and $10 \mathrm{mM}$ HEPES, $\mathrm{pH}$ 7.4. The supernatant was collected and used for the ATP assay. The assay was performed following the ATPlite Assay Kit protocol instructions using white polystyrene 96-well Costar plates (Corning Inc., Corning, NY). Luminescence was measured with a POLARstar Optima microplate reader (BMG Labtech $\mathrm{GmbH}$, Ortenberg, Germany).

\section{Statistical Analysis}

We used HEKA FitMaster software for patch-clamp data analysis. Further analysis was performed using Origin 8.5 (OriginLab, Northampton, MA). The paired two-tailed $t$ test was used to assess significant differences. Dose-response fitting was performed using the Hill function. Data are presented as means \pm S.E.M. $P<0.05$ was accepted as significant.

\section{Results}

\section{Agonist Activity of ApppI}

First, we investigated the agonist activity of ApppI on rat recombinant P2X3 receptors expressed in HEK cells compared with responses induced by the full agonist of P2X3, $\alpha, \beta$-meATP. We found that ApppI was able to activate P2X3 receptors only in relatively high concentrations. Figure 1 illustrates the typical responses of two agonists that were both applied for 2 seconds in a $10-\mu \mathrm{M}$ concentration (Fig. 1B) and the doseresponse curve for agonist activity of $\mathrm{ApppI}\left(\mathrm{EC}_{50}=16.4 \pm 0.9 \mu \mathrm{M}\right.$, $n=7$; Fig. 1C). One distinguishing property of the P2X3 receptor is the fast (millisecond range) desensitization in the continuous presence of the agonist (Chen et al., 1995; Lewis et al., 1995; Cook and McCleskey, 1997; Jiang et al., 2003). In our experiments, both $\alpha, \beta$-meATP and ApppI induced desensitizing currents (Fig. 1B). However, the time for recovery from desensitization of $\mathrm{P} 2 \mathrm{X} 3$ receptors was longer in the case of
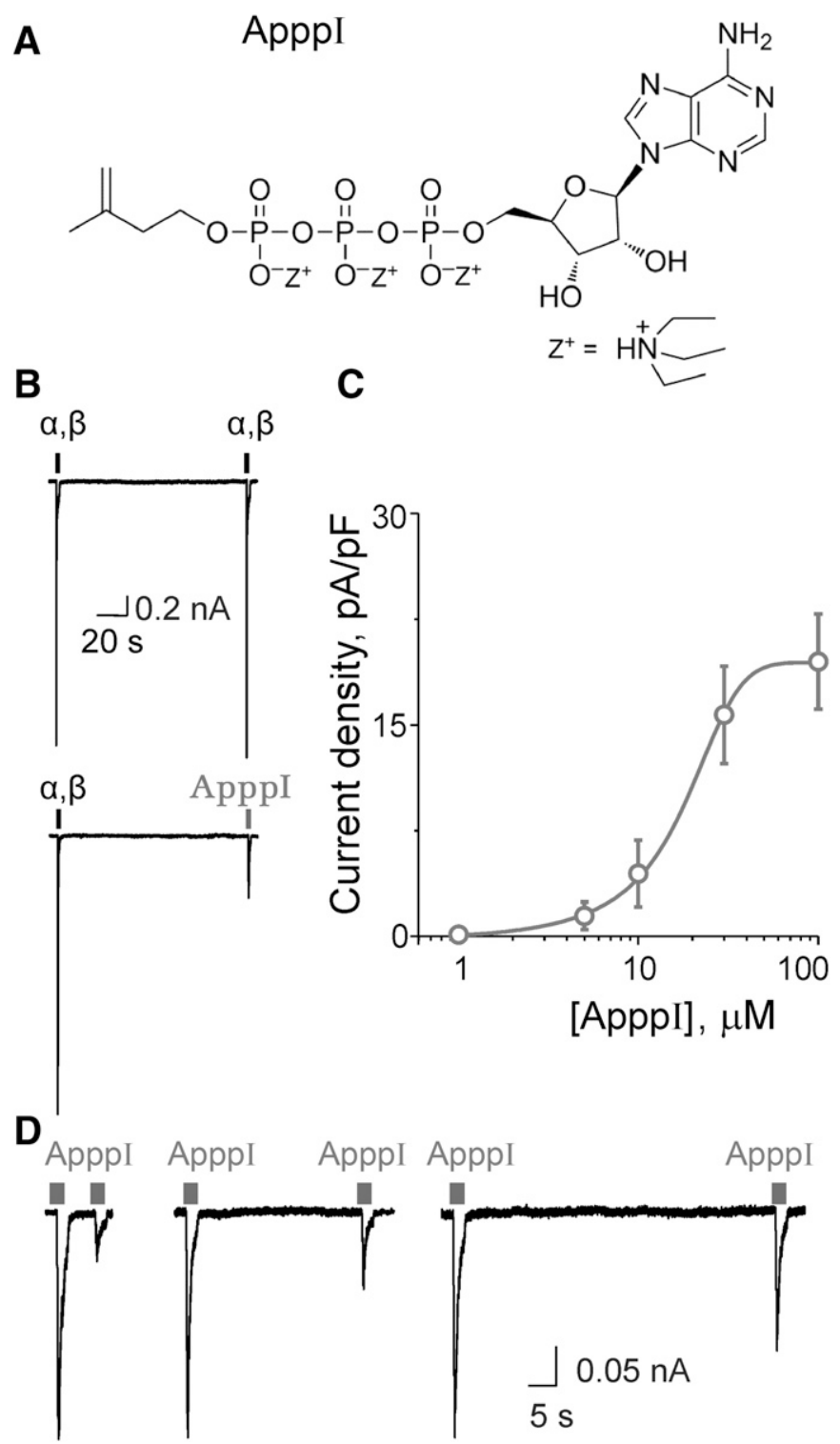

Fig. 1. Agonist activity of ApppI on P2X3 receptors. (A) Chemical structures of ApppI synthesized and used for the experiments. The chemical structure of ApppI was constructed using ChemBioDraw Ultra software. (B) Example of $\mathrm{rP} 2 \mathrm{X} 3$ receptor-mediated currents induced by application of $10 \mu \mathrm{M} \alpha, \beta$-meATP and $10 \mu \mathrm{M}$ ApppI to rP2X3-transfected HEK293 cells. (C) Dose-response curve of ApppI action on rP2X3 receptors $\left(\mathrm{EC}_{50}=16.37 \pm 0.94 \mu \mathrm{M}, n=7\right)$. (D) Example of P2X3 receptor-mediated desensitizing currents induced by paired application of $10 \mu \mathrm{M}$ ApppI. $\alpha \beta, \alpha, \beta$-meATP. 
ApppI. Thus, the paired-pulse protocol with variable intervals (5-120 seconds) indicated that the signal activated by ApppI recovered only to $68.4 \% \pm 1.2 \%$ in 2 minutes $(n=4$; Fig. $1 \mathrm{D})$, whereas recovery in this interval was almost complete for $\alpha, \beta$-meATP (Fig. 1B). In summary, membrane currents activated by $10 \mu \mathrm{M}$ ApppI were nearly 10 times lower in amplitude than currents induced by a similar concentration of $\alpha, \beta$-meATP (Fig. 1A). This indicated that ApppI is only a partial agonist of P2X3 receptors.

\section{ApppI-Induced Inhibition of P2X3 Receptors}

We then evaluated the ability of ApppI to induce a highaffinity desensitization of $\mathrm{P} 2 \mathrm{X} 3$ receptors leading to inhibitory and thus antinociceptive effects (Giniatullin et al., 2008; Viatchenko-Karpinski et al., 2016). Therefore, we tested the different concentrations of ApppI to determine its inhibitory potency on $\mathrm{rP} 2 \mathrm{X} 3$ receptors. In the control, a paired application of $10 \mu \mathrm{M} \alpha, \beta$-meATP for 2 seconds with a 120 -second interval produced membrane currents with similar amplitude (Fig. 2A). We found that even $10 \mathrm{nM}$ ApppI applied for 120 seconds between two $\alpha, \beta$-meATP test pulses was able to inhibit P2X3 receptor-mediated currents to $36 \% \pm 8 \%$ of control values $(P=0.0013, n=10$; Fig. $2 \mathrm{~B})$.
ApppI applied at the higher 100-nM concentration inhibited test currents to $15.4 \% \pm 3.9 \%$ of control values $(P=0.02$, $n=4)$, whereas $1 \mu \mathrm{M}$ ApppI reduced the $\alpha, \beta$-meATP-induced currents to $7.1 \% \pm 3.9 \%(P=0.03, n=4)$. Using the same protocol, we also tested the inhibitory potency of $10 \mathrm{nM}$ ApppI when P2X3 receptors are activated by their natural agonist ATP (Fig. 2C). We found, that $10 \mathrm{nM}$ ApppI significantly inhibited ATP-induced P2X3 currents to $42.2 \% \pm 4 \%(P=0.018, n=12$; Fig. $2 \mathrm{D})$, which was very similar to results obtained with $\alpha, \beta$-meATP. Pooled data for the inhibitory action of ApppI on $\alpha, \beta$-meATP- and ATPevoked currents are shown in Fig. $2 \mathrm{E}$.

Furthermore, to characterize the inhibitory action of ApppI, we constructed the dose-response curve for $\alpha, \beta$-meATP in the control and in the presence of $10 \mathrm{nM}$ ApppI. We found that $10 \mathrm{nM}$ ApppI strongly decreased currents induced by different concentrations of $\alpha, \beta$-meATP, indicating reduced efficacy without significant changes in affinity. Thus, the $\mathrm{EC}_{50}$ for $\alpha, \beta$-meATP-induced currents was $1.10 \pm 0.03 \mu \mathrm{M}$ in the control $(n=14)$ and $1.16 \pm 0.02 \mu \mathrm{M}$ in the ApppI-treated group ( $n=5, P>0.05$; Fig. $2 \mathrm{~F}$ ). These results indicated that ApppI is a noncompetitive antagonist, consistent with the desensitizing mechanism of its inhibitory action.

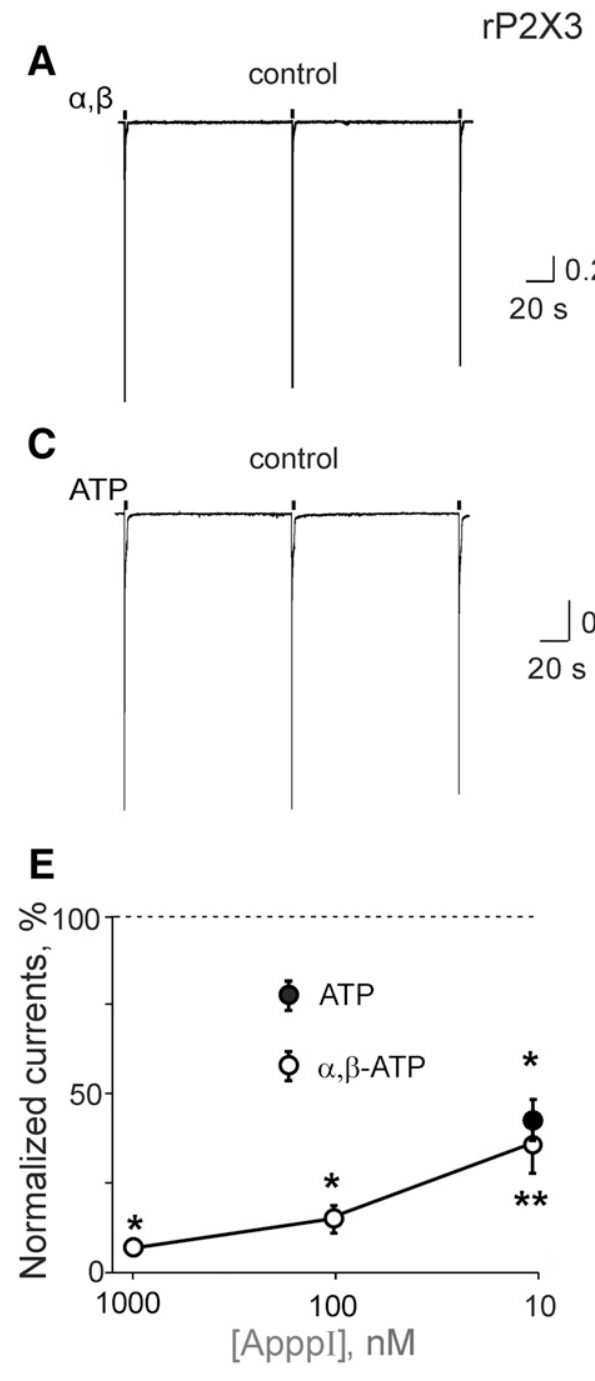

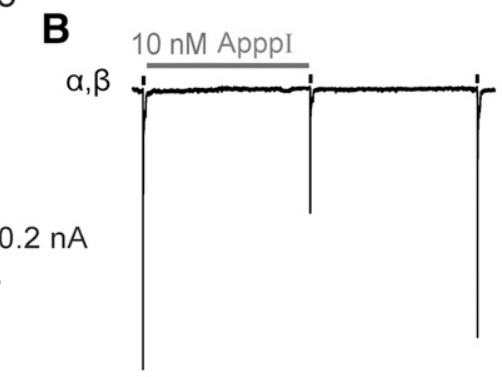
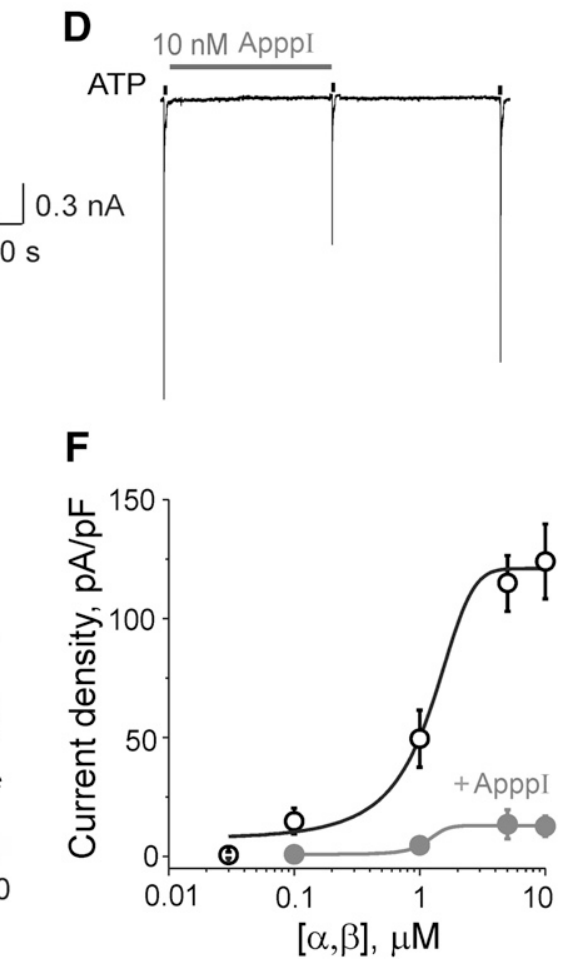

Fig. 2. Inhibitory potency of ApppI on P2X3 receptors. (A) Example of current induced by $10 \mu \mathrm{M} \alpha, \beta$-meATP applied for 2 seconds with an interval of 120 seconds. Notice the full recovery of the second current. (B) Example of the inhibitory action of $10 \mathrm{nM}$ ApppI applied for 120 seconds between two $\alpha, \beta$-meATP applications. (C) Example of current induced by $20 \mu \mathrm{M}$ ATP applied for 2 seconds with an interval of 120 seconds. (D) Example of the inhibitory action of $10 \mathrm{nM}$ ApppI applied for 120 seconds between two ATP applications, which demonstrates similar rates of ApppI inhibition for ATP and $\alpha, \beta$-meATP-induced rP2X3 currents. (E) Histograms showing the inhibitory effect of different ApppI concentrations on $\alpha, \beta$-meATP-induced currents (open white circles, $7.1 \% \pm 3.9 \%, *, P=0.03 ; 15.4 \% \pm 3.9 \%$, $*, P=0.02$; and $36 \% \pm 8 \%, * *, P=0.0013$, respectively; $n=4-10)$ and the inhibitory effect of $10 \mathrm{nM}$ ApppI on ATP-stimulated (black circles) rP2X3 currents (*, $P=0.018, n=12$ ). (F) Dose-response curves of $\alpha, \beta$-meATP alone (black line, $\mathrm{EC}_{50}=1.10 \pm 0.03 \mu \mathrm{M}$, $n=14$ ) and in the presence of $10 \mathrm{nM}$ ApppI (gray line, $\left.\mathrm{EC}_{50}=1.16 \pm 0.02 \mu \mathrm{M}, n=5\right)$ on rP2X3 receptors. $\alpha \beta$, $\alpha, \beta$-meATP. 


\section{$\mathrm{Ca}^{2+}$ Dependence of the Inhibitory Action of ApppI}

Since bone cancer is often associated with disturbances of $\mathrm{Ca}^{2+}$ homeostasis, we tested the action of ApppI in different concentrations of extracellular $\mathrm{Ca}^{2+}$. We found that in a low concentration $(0.2 \mathrm{mM})$ of extracellular $\mathrm{Ca}^{2+}, 10 \mathrm{nM}$ ApppI had the strongest depressant action on $\mathrm{rP} 2 \mathrm{X} 3$ receptors (to $12 \% \pm 3 \%$ of control, $P=0.0002, n=14$; Fig. $3, \mathrm{~A}$ and C). Lower inhibition was observed in $4 \mathrm{mM} \mathrm{Ca}^{2+}$ (to $68 \% \pm 8 \%$, $P=0.035, n=4$; Fig. 3C). In sharp contrast, in a high concentration $\left(10 \mathrm{mM}\right.$ ) of extracellular $\mathrm{Ca}^{2+}$ (which corresponds to severe hypercalcemia), we did not observe significant current suppression by ApppI $(86 \% \pm 10 \%, P>0.1, n=7$; Fig. 3, B and C).

\section{Selectivity of ApppI Action on P2X3 Subtype}

To determine the specificity of ApppI action on pronociceptive P2X3 receptors, we tested the action of this agent on $\mathrm{rP} 2 \mathrm{X} 2$ receptors expressed in HEK293 cells. We did not detect any agonist activity for the relatively high $(10 \mu \mathrm{M})$ concentration

$\mathrm{rP} 2 \mathrm{X3}$
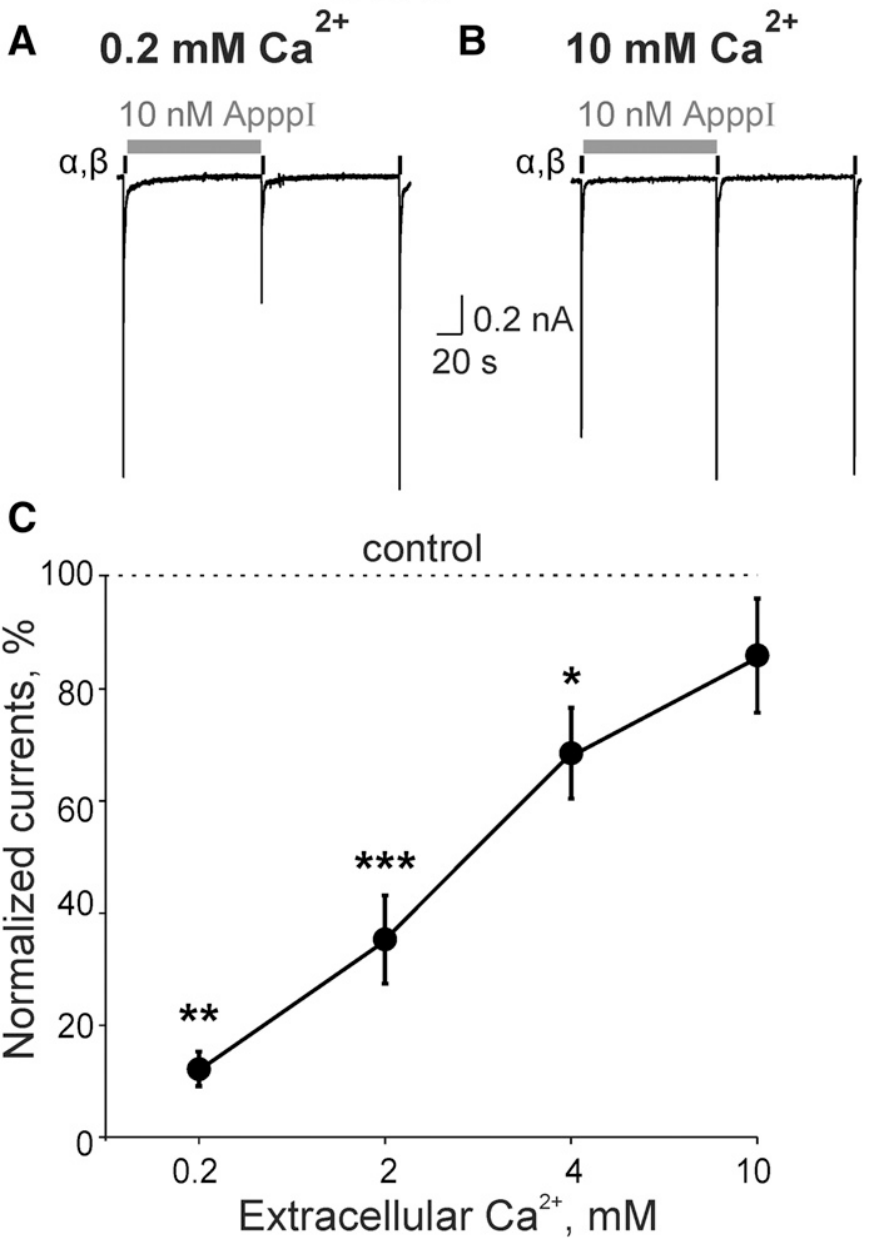

Fig. 3. $\mathrm{Ca}^{2+}$-dependent inhibitory action of ApppI on $\mathrm{rP} 2 \mathrm{X} 3$ receptors. (A) Example of the inhibitory action of $10 \mathrm{nM}$ ApppI in low $(0.2 \mathrm{mM})$ extracellular $\mathrm{Ca}^{2+}$. (B) Example of ApppI (10 nM) application in high $(10 \mathrm{mM})$ extracellular $\mathrm{Ca}^{2+}$. (C) Histograms showing the $\mathrm{Ca}^{2+}$-dependent action of $10 \mathrm{nM}$ ApppI on rat recombinant $\mathrm{rP2X} 3$ receptors $(* * *, P=$ $0.0002, n=14$; **, $P=0.0013, n=10 ; *, P=0.035, n=4$; and $P>0.1, n=7$, respectively, for $0.2,2,4$, and $10 \mathrm{mM}$ extracellular $\mathrm{Ca}^{2+}$ ). $\alpha \beta, \alpha, \beta$-meATP. of ApppI on rP2X2 receptors, although we did observe a large response with $10 \mu \mathrm{M}$ ATP ( $n=4$; Fig. 4A). We also did not observe any inhibitory effect of ApppI on $\mathrm{rP} 2 \mathrm{X} 2$ receptors $(n=4$; Fig. 4B). Likewise, we observed neither an agonist nor antagonist (inhibitory) action of ApppI on rP2X7 receptors ( $n=4$; Fig. $4, \mathrm{C}$ and D). These data suggest that ApppI acts specifically on $\mathrm{P} 2 \mathrm{X} 3$ receptors. We further investigated the possibility that ApppI interferes with the hP2X7 and hP2X2 receptor subtypes. We used similar protocols as for $\mathrm{rP} 2 \mathrm{X} 2$ and $\mathrm{rP} 2 \mathrm{X} 7$ receptors to evaluate both the agonist and inhibitory action of ApppI. We used $1 \mathrm{mM}$ ATP For stronger stimulation of the hP2X7 receptors (Fig. 4, G and H). As with
A
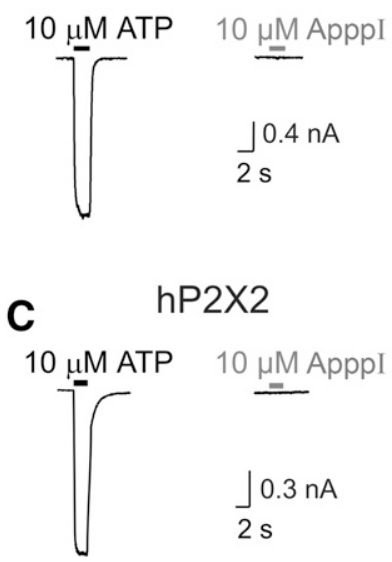

E
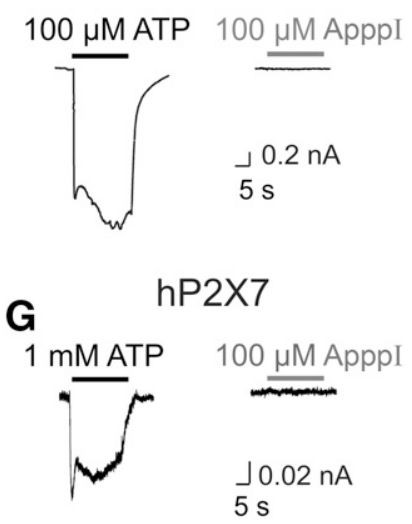

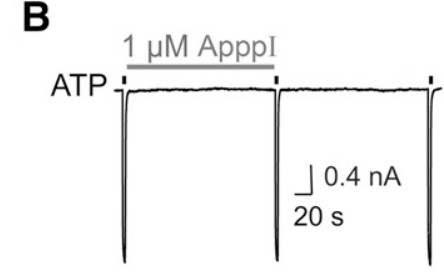

D

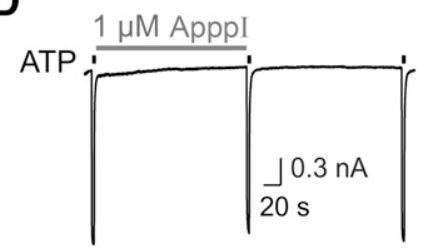

F

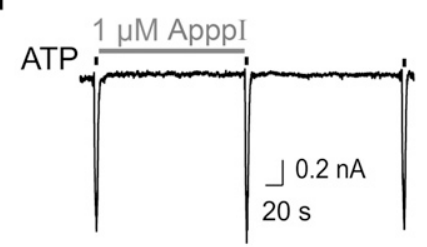

H

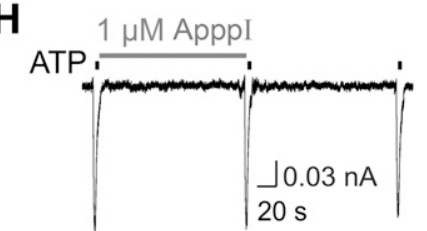

Fig. 4. Testing ApppI action on $\mathrm{P} 2 \mathrm{X} 2$ and $\mathrm{P} 2 \mathrm{X} 7$ receptors. (A) Example of ATP-activated rP2X2 receptor-mediated currents and the absence of the agonist effect of $10 \mu \mathrm{M}$ ApppI on this receptor type $(n=4)$. (B) Test of the inhibitory action of $1 \mu \mathrm{M}$ ApppI applied for 120 seconds on rP2X2 receptors $(n=4)$. Notice that even this relatively high concentration of ApppI was unable to inhibit nondesensitizing rP2X2 currents. (C) Example of ATP-activated hP2X2 receptor-mediated currents and the absence of the agonist effect of $10 \mu \mathrm{M}$ ApppI on this receptor type $(n=4)$. (D) Absence of the inhibitory action of $1 \mu \mathrm{M}$ ApppI applied for 120 seconds on hP2X2 receptors $(n=7)$. (E) Example of ATP-activated rP2X7 receptor-mediated currents showing the absence of the agonist effect of $100 \mu \mathrm{M}$ ApppI on this receptor type $(n=4)$. (F) Test of the inhibitory action of $1 \mu \mathrm{M}$ ApppI applied for 120 seconds on $\mathrm{rP} 2 \mathrm{X} 7$ receptors. Notice no effect of ApppI $(n=4)$. (G) Example of ATP-mediated $(1 \mathrm{mM}) \mathrm{hP} 2 \mathrm{X} 7$ receptor currents showing the absence of the agonist effect of $100 \mu \mathrm{M}$ ApppI on this receptor type $(n=6)$. $(\mathrm{H})$ Experimental trace demonstrating no effect after $1 \mu \mathrm{M}$ ApppI application for 120 seconds on hP2X7 receptors $(n=8)$. $\alpha \beta, \alpha, \beta$-meATP. 
the rat receptors, we found neither an agonist nor inhibitory effect of ApppI on hP2X7 and hP2X2 receptors (Fig. 4, C, D, $\mathrm{G}$, and $\mathrm{H}$ ), again suggesting that ApppI is selective for P2X3 subunit-containing receptors in both rats and humans.

We compared currents activated by $\alpha, \beta$-meATP in trigeminal and nodose ganglia because the nodose neurons, responsible for the visceral pain, express preferentially heteromeric P2X2/3 subunits that produce slow currents with little desensitization (Viatchenko-Karpinski et al., 2016). Trigeminal ganglion nociceptors take part in bone innervations; in particular, they supply the cranial periosteum (Zhao and Levy, 2014). We found that fast desensitizing currents activated with $\alpha, \beta$-meATP in trigeminal ganglion neurons were potently inhibited by $10 \mathrm{nM}$ ApppI (to $44 \% \pm 4 \%, P=0.0007, n=17$; Fig. 5A). In contrast, slow currents in nodose ganglion neurons were almost insensitive to this treatment $(90.4 \% \pm 3.4 \%$, $P>0.1, n=8$; Fig. 5B). These data also suggest the selectivity of ApppI for homomeric P2X3 receptors.

Consistent with the data from rat recombinant P2X3 receptors, we observed a strong $\mathrm{Ca}^{2+}$-dependent inhibitory action of ApppI on native $\mathrm{rP} 2 \mathrm{X} 3$ receptors in trigeminal neurons. Thus, in a low $\mathrm{Ca}^{2+}$ concentration $(0.2 \mathrm{mM})$, the test currents were suppressed by $10 \mathrm{nM}$ ApppI to $9.0 \% \pm 4.1 \%(P=$ $0.05, n=7)$; in the physiologic concentration of $\mathrm{Ca}^{2+}(2 \mathrm{mM})$, $\alpha, \beta$-meATP currents were suppressed only to $44 \%$ of the control value. In conditions mimicking hypercalcemia (10 mM), we detected no inhibitory action of ApppI on trigeminal neurons $(87.7 \% \pm 4.9 \%, P>0.5, n=10$; Fig. $5 \mathrm{C})$.

\section{ApppI Action on Human P2X3 Homolog}

For translational aspects and to explore whether this action is conserved in different species, it was interesting to study the inhibitory effect of low nanomolar ApppI on hP2X3 receptors. Interestingly, we found a very strong depressant effect of $10 \mathrm{nM}$ ApppI in the physiologic $\mathrm{Ca}^{2+}$ concentration in hP2X3 receptors compared to the rat homolog (depression to $2.7 \% \pm$ $1.0 \%, P=0.02, n=8$; Fig. 6 , A and C). Such a strong effect of low concentrations was consistent with the potential role of endogenous ApppI in human sensory neurons. Next, as with rP2X3 receptors, we characterized ApppI inhibition of hP2X3 receptors in conditions mimicking hypercalcemia (modeled with $10 \mathrm{mM} \mathrm{Ca}^{2+}$ ). As expected, the inhibitory effect of $10 \mathrm{nM}$ ApppI was almost fully eliminated in this hypercalcemia-like condition $(84 \% \pm 4 \%, n=14, P>0.05$; Fig. 6 , B and C). Thus, we confirmed the strong $\mathrm{Ca}^{2+}$ dependence of ApppI inhibition in both $\mathrm{rP} 2 \mathrm{X} 3$ and $\mathrm{hP} 2 \mathrm{X} 3$ receptors.

\section{No Direct Effect of ApppI Metabolites and Zoledronate}

To explore whether the inhibitory action of ApppI required the full molecule of ApppI or whether it was due to ApppI metabolites that could exert their own physiologic effect, we tested the action of IPP and AMP on P2X3 receptors. The same protocol of drug application as for ApppI was used for this aim. However, administration of $1 \mu \mathrm{M}$ IPP and $1 \mu \mathrm{M}$ AMP on P2X3 receptors did not produce any inhibitory effect (Fig. 7, C and D). Next, we investigated whether zoledronate (Mönkkönen et al., 2006), an inducer of ApppI, can directly inhibit P2X3 receptors. We found that $10 \mu \mathrm{M}$ zoledronate did not affect the function of $\mathrm{P} 2 \mathrm{X} 3$ receptors (Fig. 7E), suggesting a lack of direct action of this NBP on the P2X3 receptor (Fig. 7F). However, using the ATPlite Luminescence Assay System, we found that
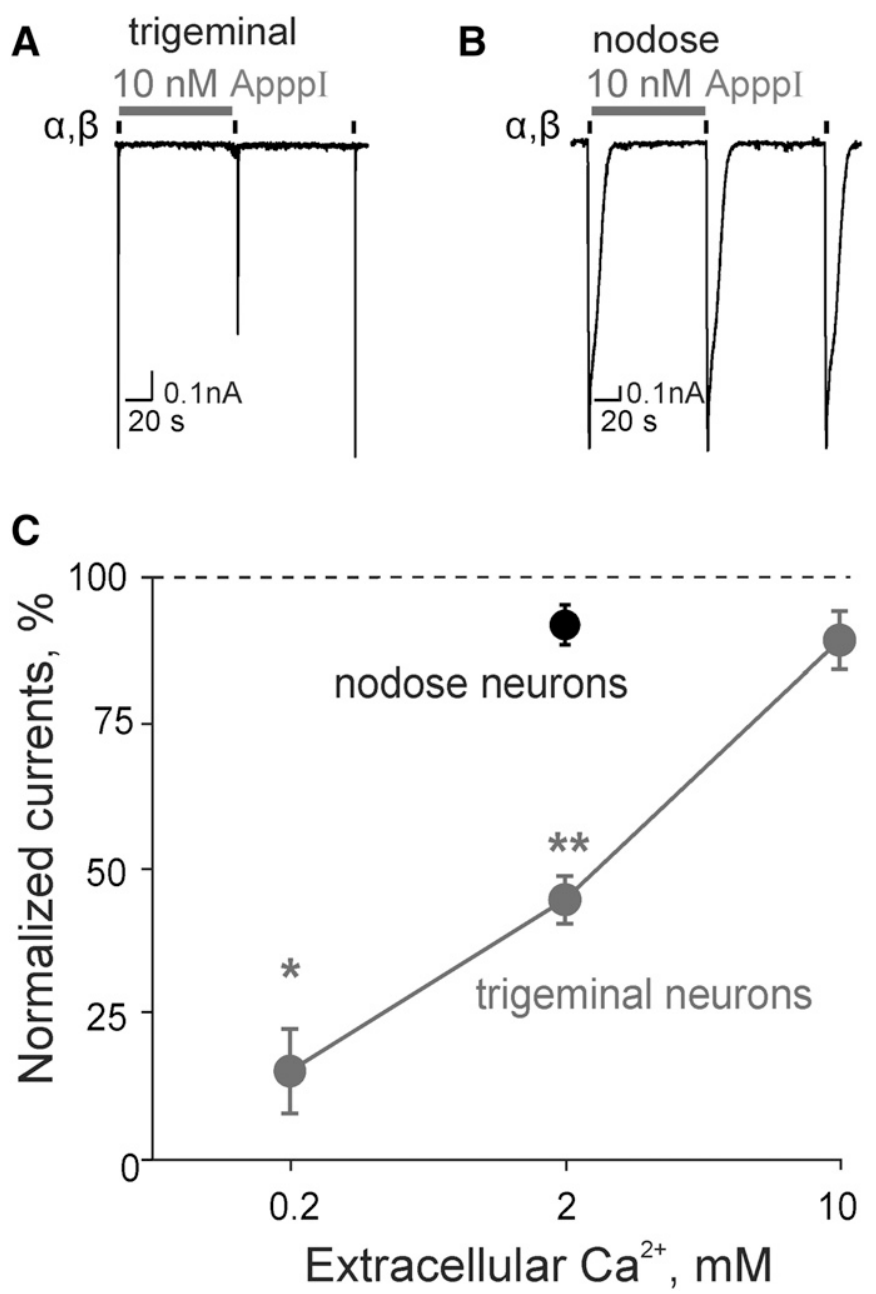

Fig. 5. Comparing ApppI inhibition in trigeminal and nodose ganglia neurons. (A) Example of $\alpha, \beta$-meATP current inhibition by $10 \mathrm{nM}$ ApppI in trigeminal ganglia neurons. (B) Example of the lack of inhibitory effect of $10 \mathrm{nM}$ ApppI on currents in nodose ganglia neurons. (C) Histograms presenting $\mathrm{Ca}^{2+}$-dependent inhibition by $10 \mathrm{nM}$ ApppI of native P2X receptors in trigeminal and nodose ganglion neurons. ( ${ }^{*}, P=0.050, n=7$; **, $P=0.0007, n=17$; and $P>0.5, n=10$ for the trigeminal ganglion in 0.2 , 2 , and $10 \mathrm{mM} \mathrm{Ca}{ }^{2+}$, respectively; $P>0.1, n=8$ for nodose ganglion neurons). $\alpha \beta, \alpha, \beta$-meATP.

zoledronate was able to induce the release of purines from cells to the extracellular medium. Thus, $100 \mu \mathrm{M}$ zoledronate applied for 24 hours to the trigeminal neuronal culture significantly increased the concentration of extracellular ATP from $0.70 \pm 0.26 \mathrm{nM}$ to $3.2 \pm 0.4 \mathrm{nM}(P=0.018, n=$ 12 and 6, respectively; Fig. 7G), suggesting a similar release of endogenous ApppI.

\section{ApppI Biodegradation}

Because many endogenous polyphosphates are quickly degraded in the live tissues by multiple nucleotidases (Yegutkin et al., 2008, 2016), we next investigated the intensity of ApppI hydrolysis in rat meninges. For that purpose, we used the lead nitrate method, based on the generation of lead orthophosphate precipitation in the course of nucleotidase activity (Yegutkin et al., 2008), which we recently optimized for application in transparent rat meninges (Yegutkin et al., 2016). We performed this labeling to evaluate the speed of 

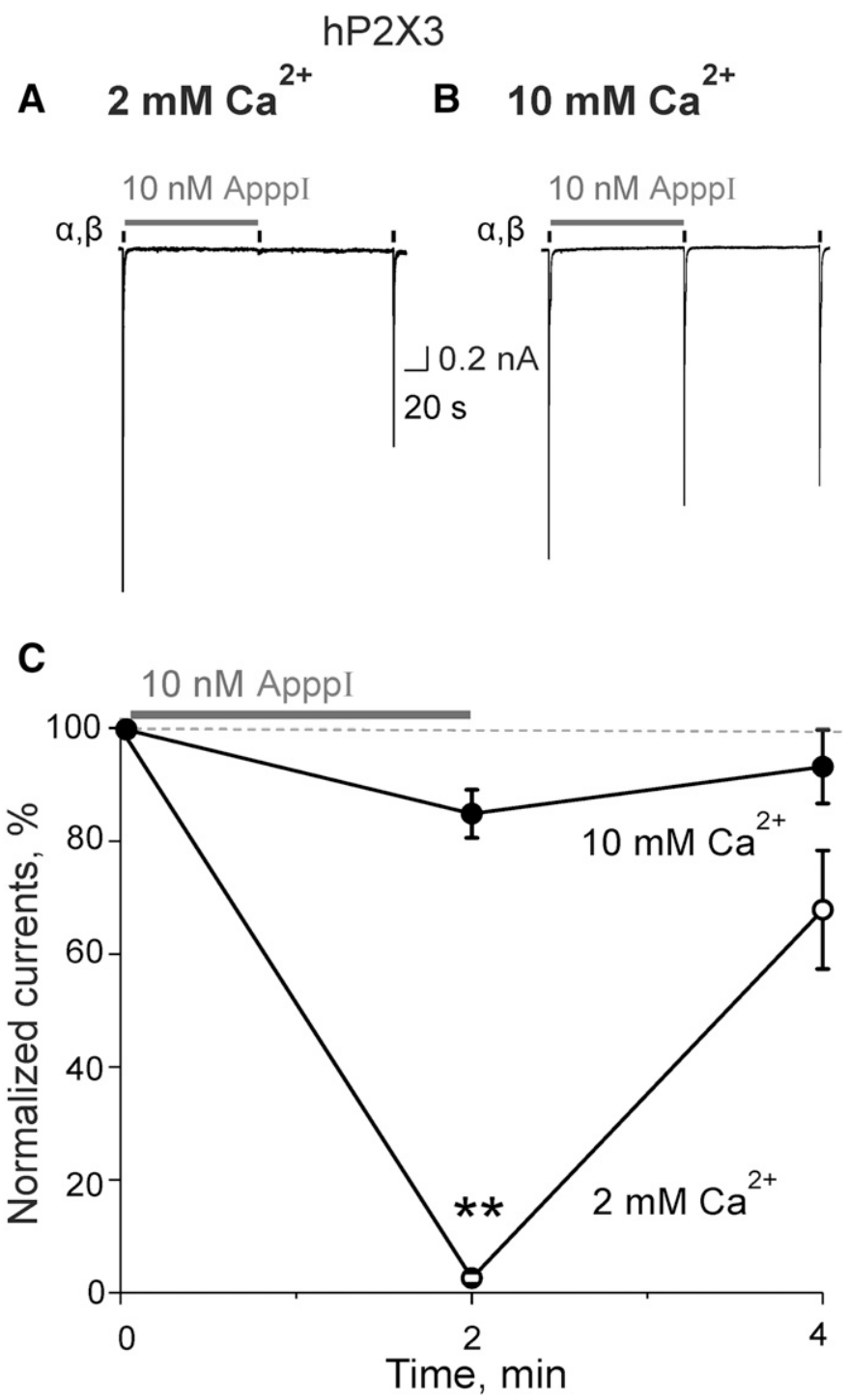

Fig. 6. ApppI inhibition of the hP2X3 subtype. (A) Example of the inhibitory action of $10 \mathrm{nM}$ ApppI in physiologic $(2 \mathrm{mM})$ extracellular $\mathrm{Ca}^{2+}$ on $\alpha, \beta$-meATP-activated currents in hP2X3 receptors. (B) Example of ApppI $(10 \mathrm{nM})$ application in high $(10 \mathrm{mM})$ extracellular $\mathrm{Ca}^{2+}$ on $\alpha, \beta$-meATP-activated currents in hP2X3 receptors. To note, the $\mathrm{Ca}^{2+}$ dependent decrease in ApppI inhibition on hP2X3 replicates the effect on the rP2X3 subtype. (C) Histograms showing statistics on the inhibition by $10 \mathrm{nM}$ ApppI and recovery of the hP2X3-induced currents in $2 \mathrm{mM}$ and $10 \mathrm{mM}$ extracellular $\mathrm{Ca}^{2+}$, respectively $(2.7 \% \pm 1.0 \%$ versus control, **, $P=0.02, n=8$, open white circles; $84 \% \pm 4 \%, n=14, P>0.5$, black circles). $\alpha \beta, \alpha, \beta$-meATP.

ApppI degradation compared with ATP. Precipitates were clearly visualized in the meninges as brown deposits around the main arteries (Yegutkin et al., 2016), which is the main site for migraine pain generation (Olesen et al., 2009; Zakharov et al., 2015). In comparing the images in Fig. 8, $\mathrm{A}-\mathrm{C}$, it is clear that the labeling was very weak in the control (without added purines), stronger with $300 \mu \mathrm{M}$ ApppI, and very intense in the case of $300 \mu \mathrm{M}$ ATP, indicating very fast degradation of phosphates from the latter compound. Pooled data are presented for this test in Fig. $8 \mathrm{D}(n=4$ for all cases). These results revealed the relative stability of ApppI versus ATP, suggesting a longer effect of the former on P2X3 receptors.
A IPP
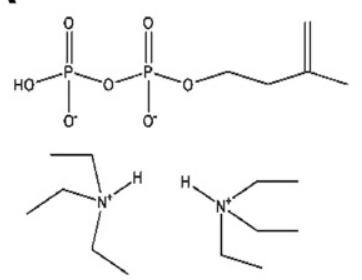

C

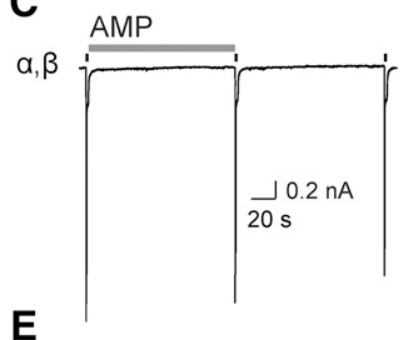

$\mathbf{E}$
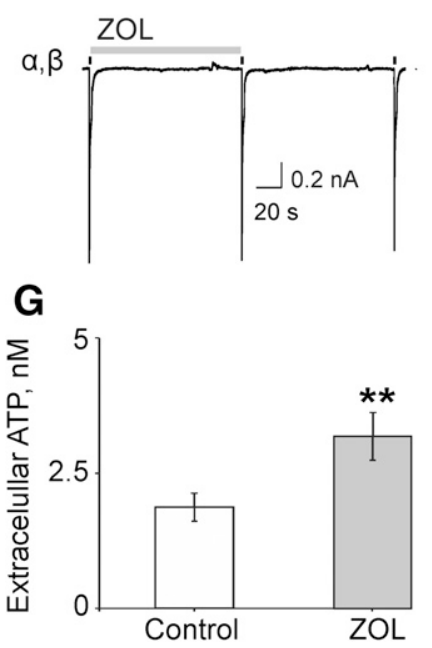

Fig. 7. Lack of the inhibitory effect of AMP, IPP, or zoledronate on P2X3 receptors. (A and B) Chemical structures of IPP and zoledronate synthesized and used for the experiments. Chemical structures of IPP and zoledronate were constructed using ChemBioDraw Ultra software. (C-E) Examples of the action of $1 \mu \mathrm{M}$ AMP, $1 \mu \mathrm{M}$ IPP, or $10 \mu \mathrm{M}$ zoledronate on $\alpha, \beta$-meATP-activated currents. (F) Histograms represent the average effects of AMP, IPP, and zoledronate on P2X3 receptors $(P \geq$ $0.9, n=10 ; P \geq 0.8, n=11$; and $P \geq 0.8, n=13$, respectively). (G) The histogram showing ATP-luminescent assay data obtained from trigeminal neurons. Notice that the extracellular ATP concentration was significantly increased after treatment with $100 \mu \mathrm{M}$ ZOL for 24 hours $(0.70 \pm$ $0.26 \mathrm{nM}, n=12$ in the control; $3.2 \pm 0.4 \mathrm{nM}, n=6$ after treatment; **, $P=0.018$ ). $\alpha \beta, \alpha, \beta$-meATP; ZOL, zoledronate.

\section{Discussion}

The main finding of this study is that the NBP-induced ATP analog ApppI has a very strong and selective inhibitory effect on pronociceptive P2X3 receptors. Relative stability and slow resensitization of receptors interacting with this compound favor the inhibitory action of endogenous ApppI. We also suggest that reducing the level of extracellular $\mathrm{Ca}^{2+}$ during bone tumor treatment with NBPs should promote the antinociceptive effect of ApppI on P2X3 receptors.

\section{Low Agonist and High Antagonist Activity of ApppI on P2X3 Receptors}

Here, we show the strong inhibition of pain transducing $\mathrm{P} 2 \mathrm{X} 3$ receptors by a low nanomolar concentration of ApppI in 

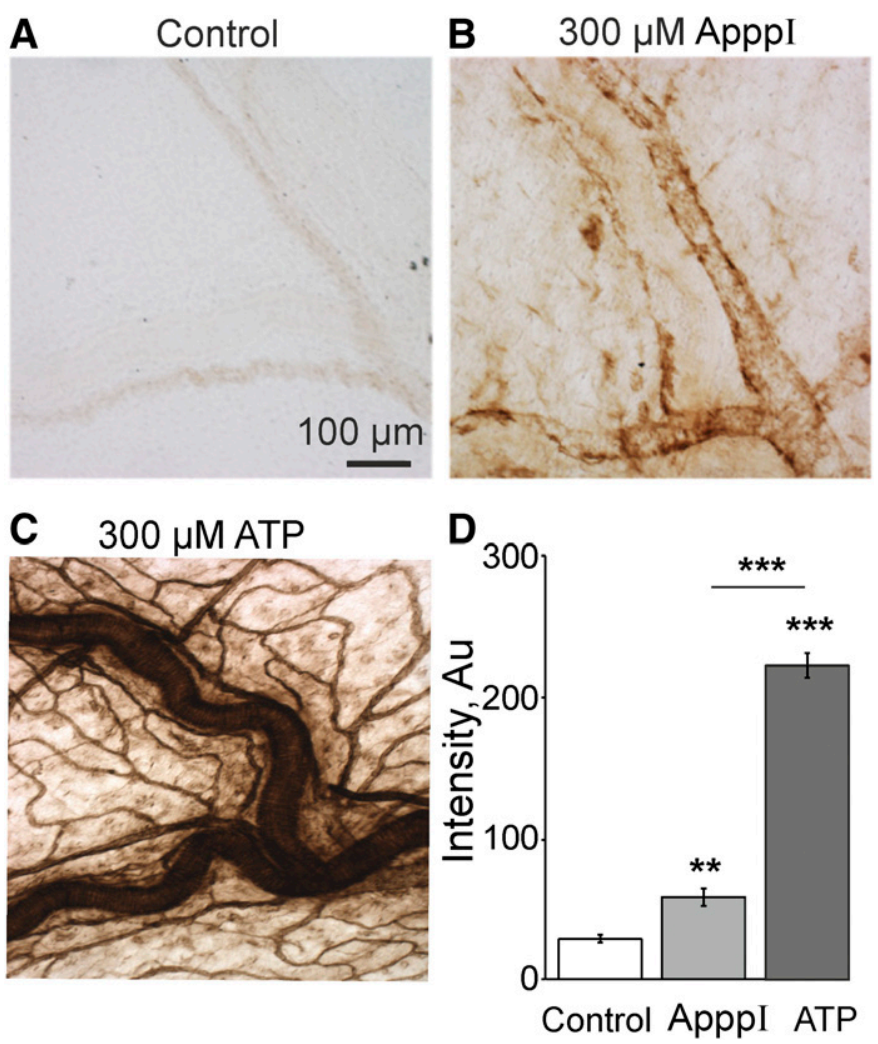

Fig. 8. Comparison of nucleotide hydrolysis of ApppI and ATP. (A-C) Images of meninges treated with vehicle (A), $300 \mu \mathrm{M}$ ApppI (B), and $300 \mu \mathrm{M}$ ATP $(C)$, respectively. The activity of nucleotidases generating phosphate due to polyphosphate hydrolysis was visualized using lead nitrate and diammonium sulphide $(n=5)$. (D) Histogram representing statistics of the signal intensity of the vessels colored after phosphate staining with added substances (control: $28.4 \pm 2.4, n=4$; ATP: $221.1 \pm 8.7$, ***, $P<0.0001$, $n=4$; ApppI: $59.6 \pm 6.3, * *, P=0.0033, n=4$ ).

trigeminal neurons and transfected HEK293 cells. Our pharmacological testing with a wide range of ApppI concentrations indicated this ATP analog to be only a weak and partial agonist of ATP-gated P2X3 receptors. Indeed, even in saturating concentrations, the currents activated by ApppI were approximately $20 \%$ of the currents induced by the full agonist of P2X3 receptors $(\alpha, \beta$-meATP). In contrast, ApppI demonstrated the ability to inhibit P2X3 receptors in impressively low nanomolar concentrations. Thus, the concentration of ApppI needed to inhibit this receptor type is approximately 10,000 times lower than the concentration required for activation. ApppI inhibition is most likely due to highaffinity desensitization (Sokolova et al., 2006), which is also observed with ATP (Sokolova et al., 2006; Giniatullin and Nistri, 2013). However, ATP is a full P2X3 agonist with limited stability, whereas the stability of ApppI appears to be much higher, a property suggesting that it is able to induce prolonged inhibitory antinociceptive action. In a previous study, we characterized synthetic $\mathrm{Ap}_{\mathrm{n}} \mathrm{A}$-analogs with comparable inhibitory action on hP2X3 receptors and antinociceptive action in vivo (Viatchenko-Karpinski et al., 2016); however, ApppI presents even better characteristics as a stronger inhibitory antinociceptive agent.

\section{Selectivity of ApppI Action}

High selectivity is essential for a potential analgesic agent. This study reveals that the action of ApppI on the P2X3 receptor is highly selective and acts as such. Whereas the ApppI metabolite AMP can act on adenosine A1 receptors (Rittiner et al., 2012) and IPP is known to inhibit transient receptor potential TRPV3 and TRPA1 channels (Bang et al., 2011), they did not show any activity on the P2X3 receptor in our study. Notably, as the other indicator of selectivity, ApppI did not show any agonist or antagonist activity on either human or rP2X2 and rP2X7 receptor subtypes. Interestingly, the action of ApppI on hP2X3 was even stronger than on the rat homolog.

We also found that the inducer of ApppI, the NBP zoledronate, did not exert any direct effect on the pronociceptive P2X3 receptors, indicating that this bisphosphonate might produce an analgesic effect indirectly through generation of endogenous ApppI.

\section{$\mathrm{Ca}^{2+}$ Dependence of ApppI Action and the Role of P2X3 Receptors in Cancer Pain}

One specific property of ApppI activity found in this study was that the inhibition of P2X3 receptors was dramatically dependent on the level of extracellular $\mathrm{Ca}^{2+}$. Importantly, the level of $\mathrm{Ca}^{2+}$ is increased in many bone cancers (Stewart, 2005; Basso et al., 2011; Coleman et al., 2014), whereas the concentration of this cation is decreased to a normal level during NBP anticancer treatment (Dodwell et al., 1992; Stewart, 2005; Basso et al., 2011). In this study, we showed that ApppI inhibition of P2X3 receptors is almost absent in a high level of extracellular $\mathrm{Ca}^{2+}$ but is very pronounced at low concentrations of this cation. Importantly, the strong inhibition of $\mathrm{hP} 2 \mathrm{X} 3$ receptors was observed in physiologic concentrations of extracellular $\mathrm{Ca}^{2+}$ but was eliminated in hypercalcemia-like conditions. Thus, we suggest that the painful stimuli resulting from activation of P2X3 receptors
A Bone cancer before treatment

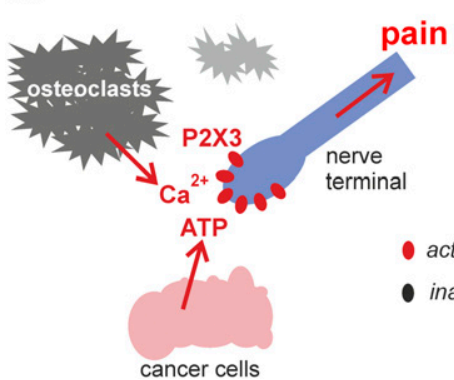

B Bisphosphonates treatment

bisphosphonates osteoblasts

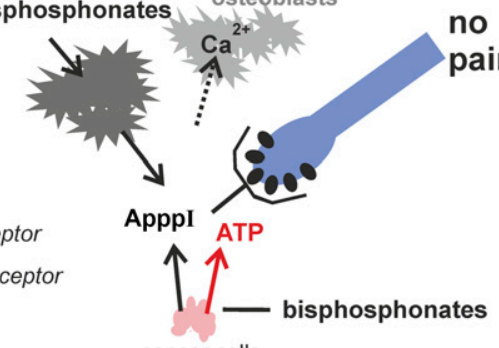

Fig. 9. Schematic presentation of the potential action of NBP and ApppI on P2X3-mediated bone cancer pain. (A) Presentation of the cancer-related local bone environment and the potential role of P2X3 receptors in mediating bone cancer pain. Notice the ATP release from cancer cells, associated hypercalcemia, and $\mathrm{Ca}^{2+}$-dependent persistent activation of painful $\mathrm{P} 2 \mathrm{X} 3$ receptors in the cancer state. (B) Cancer treatment with NBP leads to less bone resorption and a lower level of extracellular $\mathrm{Ca}^{2+}$, which is taken up into osteoblasts. All of this promotes the inhibitory action of NBP-induced ApppI on the pronociceptive P2X3 receptors, resulting in pain relief. Red lines indicate pronociceptive effects, whereas black lines show antinociceptive effects. 
in bone cancer tissues (Hukkanen et al., 1992; Kaan et al., 2010; Falk et al., 2012; Burnstock and Di Virgilio, 2013; Zhao and Levy, 2014) are amplified by high levels of extracellular $\mathrm{Ca}^{2+}$ (Giniatullin et al., 2003; Petrenko et al., 2011; Giniatullin and Nistri, 2013). During NBP treatment, NBPinduced endogenous ApppI, assisted by normalized (reduced from hypercalcemia) $\mathrm{Ca}^{2+}$ concentrations, could inactivate $\mathrm{P} 2 \mathrm{X} 3$ receptors. The schematic presentation of these findings is depicted in Fig. 9. ATP-activated P2X3 receptors, the most common type of nociceptors expressed in sensory neurons (Chen et al., 1995; Lewis et al., 1995; Simonetti et al., 2006), are activated by ATP released from multiple cellular sources, including cancer cells (Fig. 9A). Elevated $\mathrm{Ca}^{2+}$, resulting from bone cancer, helps to keep P2X3 receptor activity at a high level. We propose that cancer treatment with NBP not only generates endogenous ApppI but also sensitizes sensory neurons to ApppI inhibition via a reduced level of extracellular $\mathrm{Ca}^{2+}$ (Fig. 9B). Importantly, previous studies showed that antagonists of P2X3 receptors were able to decrease bone pain (Mach et al., 2002; Falk et al., 2012), which supports the proposed purinergic mechanism for pain relief.

This study clarifies previously unexplored mechanisms of antinociception induced by NBP and proposes the analgesic role of the endogenous ATP analog generated during bone cancer treatment. We suggest that pain relief derived from NBPs includes ApppI-induced inactivation of the P2X3 receptors, further amplified by a lowered level of extracellular $\mathrm{Ca}^{2+}$. The high efficiency of ApppI in the inactivation of pain receptors can help to design new types of antinociceptive agents to manage painful bone cancer and bone metastases.

\section{Authorship Contributions}

Participated in research design: Määttä, Mönkkönen, Giniatullin. Conducted experiments: Ishchenko, Shakirzyanova, Giniatullina, Skorinkin.

Contributed new reagents or analytic tools: Turhanen.

Performed data analysis: Ishchenko, Shakirzyanova, Giniatullina.

Wrote or contributed to the writing of the manuscript: Ishchenko, Shakirzyanova, Giniatullina, Skorinkin, Bart, Turhanen, Määttä, Mönkkönen, Giniatullin.

\section{References}

Abe Y, Iba K, Takada J, Wada T, and Yamashita T (2011) Improvement of pain and regional osteoporotic changes in the foot and ankle by low-dose bisphosphonate therapy for complex regional pain syndrome type I: a case series. J Med Case Reports 5:349.

Bang S, Yoo S, Yang TJ, Cho H, and Hwang SW (2011) Isopentenyl pyrophosphate is a novel antinociceptive substance that inhibits TRPV3 and TRPA1 ion channels. Pain 152:1156-1164.

Basso U, Maruzzo M, Roma A, Camozzi V, Luisetto G, and Lumachi F (2011) Malignant hypercalcemia. Curr Med Chem 18:3462-3467.

Burnstock G and Di Virgilio F (2013) Purinergic signalling and cancer. Purinergic Signal 9:491-540.

Chen CC, Akopian AN, Sivilotti L, Colquhoun D, Burnstock G, and Wood JN (1995) A $\mathrm{P} 2 \mathrm{X}$ purinoceptor expressed by a subset of sensory neurons. Nature 377:428-431.

Chen Y, Li G-W, Wang C, Gu Y, and Huang L-YM (2005) Mechanisms underlying enhanced P2X receptor-mediated responses in the neuropathic pain state. Pain 119:38-48.

Cockayne DA, Hamilton SG, Zhu Q-M, Dunn PM, Zhong Y, Novakovic S, Malmberg AB, Cain G, Berson A, Kassotakis L, et al. (2000) Urinary bladder hyporeflexia and reduced pain-related behaviour in P2X3-deficient mice. Nature 407:1011-1015.

Coleman R, Body JJ, Aapro M, Hadji P, and Herrstedt J; ESMO Guidelines Working Group (2014) Bone health in cancer patients: ESMO Clinical Practice Guidelines. Ann Oncol 25 (Suppl 3):iii124-iii137.

Cook SP and McCleskey EW (1997) Desensitization, recovery and $\mathrm{Ca}(2+)$-dependent modulation of ATP-gated P2X receptors in nociceptors. Neuropharmacology 36: 1303-1308.

Cook SP, Rodland KD, and McCleskey EW (1998) A memory for extracellular Ca2+ by speeding recovery of P2X receptors from desensitization. $J$ Neurosci 18: 9238-9244.

Debiais F (2013) [Bone targeting agents: bisphosphonates]. Bull Cancer 100: 1199-1206.
Dodwell DJ, Howell A, Morton AR, Daley-Yates PT, and Hoggarth CR (1992) Infusion rate and pharmacokinetics of intravenous pamidronate in the treatment of tumourinduced hypercalcaemia. Postgrad Med J 68:434-439.

Endres DB (2012) Investigation of hypercalcemia. Clin Biochem 45:954-963.

Fabbretti E, Sokolova E, Masten L, D'Arco M, Fabbro A, Nistri A, and Giniatullin R (2004) Identification of negative residues in the P2X3 ATP receptor ectodomain as structural determinants for desensitization and the Ca2+-sensing modulatory sites. J Biol Chem 279:53109-53115.

Falk S, Uldall M, and Heegaard AM (2012) The role of purinergic receptors in cancerinduced bone pain. J Osteoporos 2012:758181.

Fijorek K, Püsküllüoğlu M, Tomaszewska D, Tomaszewski R, Glinka A, and Polak S (2014) Serum potassium, sodium and calcium levels in healthy individuals - literature review and data analysis. Folia Med Cracov 54:53-70.

Frith JC, Mönkkönen J, Auriola S, Mönkkönen H, and Rogers MJ (2001) The molecular mechanism of action of the antiresorptive and antiinflammatory drug clodronate: evidence for the formation in vivo of a metabolite that inhibits bone resorption and causes osteoclast and macrophage apoptosis. Arthritis Rheum 44: 2201-2210.

Fujita T, Ohue M, Fujii Y, Miyauchi A, and Takagi Y (2009) Comparison of the analgesic effects of bisphosphonates: etidronate, alendronate and risedronate by electroalgometry utilizing the fall of skin impedance. J Bone Miner Metab 27: 234-239.

Gilchrist LS, Cain DM, Harding-Rose C, Kov AN, Wendelschafer-Crabb G, Kennedy WR, and Simone DA (2005) Re-organization of P2X3 receptor localization on epidermal nerve fibers in a murine model of cancer pain. Brain Res 1044:197-205.

Giniatullin R and Nistri A (2013) Desensitization properties of P2X3 receptors shaping pain signaling. Front Cell Neurosci 7:245.

Giniatullin R, Nistri A, and Fabbretti E (2008) Molecular mechanisms of sensitization of pain-transducing P2X3 receptors by the migraine mediators CGRP and NGF. Mol Neurobiol 37:83-90.

Giniatullin R, Sokolova E, and Nistri A (2003) Modulation of P2X3 receptors by $\mathrm{Mg} 2+$ on rat DRG neurons in culture. Neuropharmacology 44:132-140.

Goldner W (2016) Cancer-related hypercalcemia. J Oncol Pract 12:426-432.

Green JR (2004) Bisphosphonates: preclinical review. Oncologist 9 (Suppl 4):3-13.

Hansen RR, Nasser A, Falk S, Baldvinsson SB, Ohlsson PH, Bahl JMC, Jarvis MF, Ding M, and Heegaard A-M (2012) Chronic administration of the selective P2X3, P2X2/3 receptor antagonist, A-317491, transiently attenuates cancer-induced bone pain in mice. Eur $J$ Pharmacol 688:27-34.

Hu MI, Glezerman I, Leboulleux S, Insogna K, Gucalp R, Misiorowski W, Yu B, Ying W, and Jain RK (2013) Denosumab for patients with persistent or relapsed hypercalcemia of malignancy despite recent bisphosphonate treatment. J Natl Cancer Inst 105:1417-1420.

Hukkanen M, Konttinen YT, Rees RG, Santavirta S, Terenghi G, and Polak JM (1992) Distribution of nerve endings and sensory neuropeptides in rat synovium, meniscus and bone. Int $J$ Tissue React 14:1-10.

Jiang L-H, Kim M, Spelta V, Bo X, Surprenant A, and North RA (2003) Subunit arrangement in P2X receptors. J Neurosci 23:8903-8910.

Jindrichova M, Khafizov K, Skorinkin A, Fayuk D, Bart G, Zemkova H, and Giniatullin R (2011) Highly conserved tyrosine 37 stabilizes desensitized states and restricts calcium permeability of ATP-gated P2X3 receptor. J Neurochem 119:676-685.

Kaan TKY, Yip PK, Patel S, Davies M, Marchand F, Cockayne DA, Nunn PA, Dickenson AH, Ford APDW, Zhong Y, et al. (2010) Systemic blockade of P2X3 and $\mathrm{P} 2 \mathrm{X} 2 / 3$ receptors attenuates bone cancer pain behaviour in rats. Brain 133: $2549-2564$

Kao CL, Kittleman W, Zhang H, Seto H, and Liu HW (2005) Stereochemical analysis of isopentenyl diphosphate isomerase type II from Staphylococcus aureus using chemically synthesized (S)- and (R)-[2-2H]isopentenyl diphosphates. Org Lett 7: $5677-5680$

Kavanagh KL, Guo K, Dunford JE, Wu X, Knapp S, Ebetino FH, Rogers MJ, Russell RGG, and Oppermann U (2006) The molecular mechanism of nitrogen-containing bisphosphonates as antiosteoporosis drugs. Proc Natl Acad Sci USA 103: 7829-7834.

Lehenkari PP, Kellinsalmi M, Näpänkangas JP, Ylitalo KV, Mönkkönen J, Rogers MJ, Azhayev A, Väänänen HK, and Hassinen IE (2002) Further insight into mechanism of action of clodronate: inhibition of mitochondrial ADP/ATP translocase by a nonhydrolyzable, adenine-containing metabolite. Mol Pharmacol 61: $1255-1262$

Lewis C, Neidhart S, Holy C, North RA, Buell G, and Surprenant A (1995) Coexpression of P2X2 and P2X3 receptor subunits can account for ATP-gated currents in sensory neurons. Nature 377:432-435.

Li B-Y and Schild JH (2007) Electrophysiological and pharmacological validation of vagal afferent fiber type of neurons enzymatically isolated from rat nodose ganglia. $J$ Neurosci Methods 164:75-85.

Lin JH (1996) Bisphosphonates: a review of their pharmacokinetic properties. Bone 18:75-85.

Luger NM, Mach DB, Sevcik MA, and Mantyh PW (2005) Bone cancer pain: from model to mechanism to therapy. J Pain Symptom Manage 29 (Suppl):S32-S46.

Mach DB, Rogers SD, Sabino MC, Luger NM, Schwei MJ, Pomonis JD, Keyser CP, Clohisy DR, Adams DJ, O'Leary P, et al. (2002) Origins of skeletal pain: sensory and sympathetic innervation of the mouse femur. Neuroscience 113:155-166.

Maier GS, Eberhardt C, and Kurth AA (2015) Ibandronate: The loading dose concept in the treatment of metastatic bone pain. $J$ Bone Oncol 5:1-4.

Mantyh PW (2014) Bone cancer pain: from mechanism to therapy. Curr Opin Support Palliat Care 8:83-90.

McGaraughty S, Wismer CT, Zhu CZ, Mikusa J, Honore P, Chu KL, Lee C-H, Faltynek CR, and Jarvis MF (2003) Effects of A-317491, a novel and selective $\mathrm{P} 2 \mathrm{X} 3 / \mathrm{P} 2 \mathrm{X} 2 / 3$ receptor antagonist, on neuropathic, inflammatory and chemogenic nociception following intrathecal and intraplantar administration. Br J Pharmacol 140:1381-1388. 
Mercier N, Kiviniemi TO, Saraste A, Miiluniemi M, Silvola J, Jalkanen S, and Yegutkin GG (2012) Impaired ATP-induced coronary blood flow and diminished aortic NTPDase activity precede lesion formation in apolipoprotein E-deficient mice. Am J Pathol 180:419-428.

Mönkkönen H, Auriola S, Lehenkari P, Kellinsalmi M, Hassinen IE, Vepsäläinen J, and Mönkkönen J (2006) A new endogenous ATP analog (ApppI) inhibits the mitochondrial adenine nucleotide translocase (ANT) and is responsible for the apoptosis induced by nitrogen-containing bisphosphonates. $\mathrm{Br} J$ Pharmacol 147:437-445.

Nagae M, Hiraga T, Wakabayashi H, Wang L, Iwata K, and Yoneda T (2006) Osteoclasts play a part in pain due to the inflammation adjacent to bone. Bone $\mathbf{3 9}$ 1107-1115.

Olesen J, Burstein R, Ashina M, and Tfelt-Hansen P (2009) Origin of pain in migraine: evidence for peripheral sensitisation. Lancet Neurol 8:679-690.

Petrenko N, Khafizov K, Tvrdonova V, Skorinkin A, and Giniatullin R (2011) Role of the ectodomain serine 275 in shaping the binding pocket of the ATP-gated P2X3 receptor. Biochemistry 50:8427-8436.

Rahil A and Khan FY (2012) Humoral hypercalcemic crisis in a pregnant woman with uterine leiomyoma. J Emerg Trauma Shock 5:87-89.

Räikkönen J, Crockett JC, Rogers MJ, Mönkkönen H, Auriola S, and Mönkkönen J (2009) Zoledronic acid induces formation of a pro-apoptotic ATP analogue and isopentenyl pyrophosphate in osteoclasts in vivo and in MCF-7 cells in vitro. $\mathrm{Br} J$ Pharmacol 157:427-435.

Räikkönen J, Mönkkönen H, Auriola S, and Mönkkönen J (2010) Mevalonate pathway intermediates downregulate zoledronic acid-induced isopentenyl pyrophosphate and ATP analog formation in human breast cancer cells. Biochem Pharmacol 79:777-783.

Räikkönen J, Taskinen M, Dunford JE, Mönkkönen H, Auriola S, and Mönkkönen J (2011) Correlation between time-dependent inhibition of human farnesyl pyrophosphate synthase and blockade of mevalonate pathway by nitrogen-containing bisphosphonates in cultured cells. Biochem Biophys Res Commun 407:663-667.

Rittiner JE, Korboukh I, Hull-Ryde EA, Jin J, Janzen WP, Frye SV, and Zylka MJ (2012) AMP is an adenosine A1 receptor agonist. J Biol Chem 287:5301-5309.

Rogers MJ, Crockett JC, Coxon FP, and Mönkkönen J (2011) Biochemical and molecular mechanisms of action of bisphosphonates. Bone 49:34-41.

Russell RGG (2011) Bisphosphonates: the first 40 years. Bone 49:2-19.

Serrano A, Mo G, Grant R, Paré M, O’Donnell D, Yu XH, Tomaszewski MJ, Perkins MN, Séguéla P, and Cao CQ (2012) Differential expression and pharmacology of native P2X receptors in rat and primate sensory neurons. $J$ Neurosci 32 11890-11896.

Simonetti M, Fabbro A, D’Arco M, Zweyer M, Nistri A, Giniatullin R, and Fabbretti E (2006) Comparison of P2X and TRPV1 receptors in ganglia or primary culture of trigeminal neurons and their modulation by NGF or serotonin. Mol Pain 2:11.

Sokolova E, Skorinkin A, Moiseev I, Agrachev A, Nistri A, and Giniatullin R (2006) Experimental and modeling studies of desensitization of P2X3 receptors. $\mathrm{Mol}$ Pharmacol 70:373-382.
Souslova V, Cesare P, Ding Y, Akopian AN, Stanfa L, Suzuki R, Carpenter K, Dickenson A, Boyce S, Hill R, et al. (2000) Warm-coding deficits and aberrant inflammatory pain in mice lacking P2X3 receptors. Nature 407:1015-1017.

Stewart AF (2005) Hypercalcemia associated with cancer. N Engl J Med 352: 373-379.

Tagiyev A, Demirbilek H, Tavil B, Buyukyilmaz G, Gumruk F, and Cetin M (2016) Severe hypercalcemia in a child with acute lymphoblastic leukemia relapse: successful management with combination of calcitonin and bisphosphonate. J Pediatr Hematol Oncol 38:232-234.

van den Beuken-van Everdingen MHJ, Hochstenbach LMJ, Joosten EAJ, TjanHeijnen VCG, and Janssen DJA (2016) Update on prevalence of pain in patients with cancer: systematic review and meta-analysis. J Pain Symptom Manage 51: $1070-1090$

Weisell J, Vepsäläinen J, and Turhanen PA (2015) Two strategies for the synthesis of the biologically important ATP analogue ApppI, at a multi-milligram scale. Beilstein J Org Chem 11:2189-2193.

Viatchenko-Karpinski V, Novosolova N, Ishchenko Y, Azhar MA, Wright M, Tsintsadze V, Kamal A, Burnashev N, Miller AD, Voitenko N, et al. (2016) Stable, synthetic analogs of diadenosine tetraphosphate inhibit rat and human P2X3 receptors and inflammatory pain. Mol Pain 12:1-16.

Wu JX, Xu MY, Miao XR, Lu ZJ, Yuan XM, Li XQ, and Yu WF (2012) Functional up-regulation of $\mathrm{P} 2 \mathrm{X} 3$ receptors in dorsal root ganglion in a rat model of bone cancer pain. Eur J Pain 16:1378-1388.

Yegutkin GG, Guerrero-Toro C, Kilinc E, Koroleva K, Ishchenko Y, Abushik P, Giniatullina R, Fayuk D, and Giniatullin R (2016) Nucleotide homeostasis and purinergic nociceptive signaling in rat meninges in migraine-like conditions. Purinergic Signal 12:561-574.

Yegutkin GG, Jankowski J, Jalkanen S, Günthner T, Zidek W, and Jankowski V (2008) Dinucleotide polyphosphates contribute to purinergic signalling via inhibition of adenylate kinase activity. Biosci Rep 28:189-194.

Zakharov A, Vitale C, Kilinc E, Koroleva K, Fayuk D, Shelukhina I, Naumenko N, Skorinkin A, Khazipov R, and Giniatullin R (2015) Hunting for origins of migraine pain: cluster analysis of spontaneous and capsaicin-induced firing in meningeal trigeminal nerve fibers. Front Cell Neurosci 9:287.

Zhao J and Levy D (2014) The sensory innervation of the calvarial periosteum is nociceptive and contributes to headache-like behavior. Pain 155:1392-1400.

Address correspondence to: Rashid Giniatullin, A. I. Virtanen Institute, University of Eastern Finland, P.O. Box 1627 (Neulaniementie 2), 70211 Kuopio, Finland. E-mail: rashid.giniatullin@uef.fi or Yevheniia Ishchenko, A. I. Virtanen Institute, University of Eastern Finland, P.O. Box 1627 (Neulaniementie 2), 70211 Kuopio, Finland. E-mail: yevheniia.ishchenko@uef.fi or 